\title{
Factors Influencing the College Choice Decisions of Community College Student-Athletes
}

\author{
Nicole Meulemans ${ }^{2}$, Jon Lim ${ }^{1 *}$, Bryan Romsa ${ }^{3}$, Katelyn Romsa ${ }^{3}$ \\ ${ }^{1}$ Department of Sport Management, Minnesota State University, Mankato \\ ${ }^{2}$ Dakota County Technical College \\ ${ }^{3}$ South Dakota State University
}

*Corresponding Author: Jon Lim, Department of Sport Management, Minnesota State University, Mankato

\begin{abstract}
A decision to attend college is based on many academic and athletic factors. Identifying factors most influential in college selection is beneficial to college administrators, recruiters, and coaches, and will ultimately influence recruitment, retention, and short and long-term strategic plans of an institution. This study examined factors influencing the college choice decisions of community college student-athletes in the Midwestern United States. Participants for this study were composed of 107 student-athletes (59 males and 48 females) from 19 community colleges in the Midwest regions of the National Junior College Athletic Conference (NJCAC). This study discovered that the three most significant factors in college selection were (a) athletics/sports/extracurricular activities, (b) cost of attendance/tuition fees, and (c) head coach and coaching staff. Men selected more "athletically related factors" as influential, whereas women selected "nonathletic" as more influential. Practitioners may use this information to effectively shape their recruiting and marketing practices.
\end{abstract}

Keywords: Community College Athletes; College Choice Factors; College Selection Process

\section{INTRODUCTION}

Over the past three decades participation rates for both male and female student-athletes participating in National Collegiate Athletic Association (NCAA) sports has grown to an all-time high (NCAA, 2019). Nearly half a million college athletes make up the 19,750 teams that send more than 52,500 participants to compete each year in the NCAA's 90 championships in 24 sports across 3 divisions. According to the recent NCAA Sports Sponsorship and Participation Rates Report, there were a total of 494,992 student-athletes competing in 24 sports at the Division I, II, and III, with the number of teams competing in NCAA championship sponsored sports continued to rise to a record of more than 19,000 during 2017-18 academic year (NCAA, 2018). Considering the ever-increasing number of collegiate student-athletes, intercollegiate athletics are an essential aspect of both higher education and American culture (Up the grove, Roscigno, \& Charles, 1999). Furthermore, most higher education leaders agree that athletics are an important component of colleges and universities (Perna, 2014). The success of intercollegiate athletic programs can positively influence institutional academic reputation (Stinson \& Howard, 2007), donations from alumnae and local boosters (Stinson \& Howard, 2004; Tucker, 2004), admission applications (Toma\& Cross, 1998), and revenues from television coverage (Fulks, 2000).

In line with this trend, community and junior college athletic programs also have experienced the growth of intercollegiate athletics (NJCAA, 2019). The National Junior College Athletic Association (NJCAA) serves over 59,000 student-athletes competing on more than 3,400 teams in sanctioned programs across the country (NJCAA, 2019). Participation in the NJCAA has been steadily increasing over the past 10 years. Currently, the NJCAA offers 15 men's sports and 13 women's sports with the highest participation numbers in baseball and softball. Additionally, the California Community College Athletic Association (CCCAA), another independent association, serves approximately 25,000 athletes at over 100 California community colleges Association (CCCAA, 2019). 
Intercollegiate athletics can play a prominent role in building and sustaining campus spirit, enhancing the student life experience, and increasing exposure of the institution to the community. In particular, growing interest in sports programs is especially strong among community colleges in the Midwest (Ashburn, 2007). These colleges aim to increase their enrollment, a common objective among schools in North Carolina, Pennsylvania, and Virginia as well. Some community colleges have perceived having athletic teams as a means to showcase their image as a "true" college (Asburn, 2007). In the current higher education environment, colleges must compete with each other to maintain or increase enrollment. For instance, community colleges have actively searched for a way to utilize their athletic program to increase enrollment of traditional college students, and enhance the diversity of the student body. Athletic programs are also part of a comprehensive student life program and are often included in a college's overall strategic plans to expand enrollment. There are many factors that influence the college choice decision of student-athletes to participate in an intercollegiate athletic program at a community college. To be successful, college coaches, recruiters, administrators, and institutions need to understand why student-athletes select one institution over another. A better understanding of factors influencing this selection process will aid intercollegiate athletic programs in developing both short-term and long-term marketing plans.

Even with over 84,000 student-athletes participated in either NJCAA or CCCAA, there is very limited literature on the student-athlete choice decision at the community college while most academic research studies regarding the college choice decision of student-athletes have focused on the sports with the NCAA Division I, II, and III institutions (Hagedorn \& Horton, 2009; Kissinger \& Miller, 2009). In addition, none of the research studies identified have specifically analyzed student-athletes in the Midwest area or student-athletes participating in the National Junior College Athletic Conference. Therefore, the purpose of this study was to examine the factors influencing the college choice decisions of NJCAA student-athletes in the Midwestern United States.

\section{Methodology}

\subsection{Participants}

The participants for this study consisted of 107 student-athletes (59 men and 48 women) from 19 community colleges in the Midwest regions of the National Junior College Athletic Conference (NJCAC). The mean age of respondents was 19.6 years old $(S D=1.37 ; 18-28)$. Sixty percent of the respondents were freshmen and $40 \%$ were sophomores. Student-athletes were asked to self-report their ethnicity which was predominantly Caucasian (85\%) with African American (8\%), Hispanic American (2\%), Asian American (4\%), and White/Pacific Islander (1\%). The male respondents participated in nine sports, including baseball, basketball, cross county, football, ice hockey, indoor track and field, outdoor track and field, soccer, and wrestling while the females participated in six sports, including basketball, cross country, fast pitch softball, outdoor track and field, soccer, and volleyball.

\subsection{Measures}

The Student-Athlete College Choice Profile Survey (SACCPS) was utilized to assess factors influencing the college choice decisions of community college student-athletes (Gabert, Hale, \& Montalvo, 1999). This SACCPS instrument has been used to study college choice factors for athletes at both NCAA Division I and IIprograms (Crowley, 2004; Goss, Jubenville, \&Orejan, 2006; Letawsky, Palmer, \& Schneider, 2005;Lim, et al., 2016; Letawsky et al., 2003). The SACCPS instrument has demonstrated adequate reliability and validity (Gabert et al., 1999; Crowley, 2004). For this study, some modifications were made with college selection factors, more specific to community college student-athletes. Also based on the results of three previous investigations (Canale\& Dunlap, 1996; Goss et al., 2006; Osborne, 2001), several questions were added to the original SACCPS to better relate to community college student-athletes. The instrument was validated by a panel of professionals. The test-retest method was used to determine the reliability of the instrument. The reliability coefficient (Cronbach's alpha) for this study was .84, which is considered an acceptable level (Nunnally and Bernstein, 1994).

The research survey was divided into three sections: (a) demographic information, (b) college selection factors, and (c) additional information. Section one of the survey includes demographic information such as age, gender, ethnicity, college, sport, high school, and freshman/sophomore year of participation. Section two contained 20 college selection factors such as degree program offered, 
head coach and coaching staff, and location of school. Participants were asked to rank these factors using a five-point Likert scale ranging from 1(No Influence" to 5 (Extremely High Influence). Section three provides the opportunity to address or list other comments relative to college selection factors.

\subsection{Procedures}

Approval was obtained from the university institutional review board to conduct this study. Next, permission was obtained from the NJCAC. To administer the survey, the names of all head coaches of men's and women's sports, athletic directors, and college presidents in both regions were obtained from the commissioners of each conference. An introductory e-mail including the purpose and timelines of the study, as well as the link to the survey, was sent to each college contact person. Coaches and administrators were asked to forward the survey link to all student-athletes so they could complete the survey electronically. A statement of confidentiality was included in the survey. Participants were made aware that the information they provided would be used for research purposes only, and answers would not be used to identify individual student-athletes. One week after the initial survey was sent a follow up e-mail to reinforce the purpose and confidentiality of the survey was sent to each college contact person. Providing alternative forms of notification, both phone and e-mail, increased the return rate and efficiency of data collection. Lastly, to achieve the highest possible response rate from the intended survey groups, a third round of follow-up phone calls and e-mails were sent to each college contact three weeks after the initial contact was made.

\subsection{Statistical Analysis}

Descriptive statistics (percentages, frequency distributions, means, ranges, and standard deviations) were utilized to describe the demographic characteristics of the participants. Initially, the internal consistency (Cronbach's alpha) of the modified SACCPS instrument was examined to ensure that it is reliable for the present sample. Nunnally and Bernstein's (1994) recommended alpha value of .70 was used to evaluate the internal consistency of the instrument. Means and standard deviations were utilized to compare factors influencing college choice decisions. Additionally, t-tests were conducted to determine significant differences in college choice factors by gender. Statistical significance was accepted at an alpha level of $\mathrm{p}<.05$.

\section{RESUlts}

\subsection{Academic and Personal Goals of Student-Athletes}

Student-athletes were asked to report their academic and personal goals for attending the community college. Table 1 shows $79 \%$ reported their academic and personal goals following two-years of college was to earn a four-year degree, seven percent wanted a two-year degree, and $12 \%$ were planning on obtaining direct employment. Two respondents $(2 \%)$ were undecided on their postcollege plans at the time of the survey. Comparing male and female academic and personal goals provided an interesting difference as a somewhat smaller but still significant number. Seventeen percent of women and $7.5 \%$ of men reported their academic goal of seeking direct employment while $80 \%$ of men and $77 \%$ of women reported their academic goal of earning a four-year degree.

Table1: Academic and Personal Goals of Student-Athletes

\begin{tabular}{|l|l|l|l|l|l|l|}
\hline & \multicolumn{2}{|l|}{ Overall } & Female & Male & $\%$ \\
\hline Goal & \multicolumn{1}{|c|}{$\mathrm{N}$} & $\%$ & $\mathrm{~N}$ & $\%$ & $\mathrm{~N}$ & 77.0 \\
\hline 4-Year Degree & 84 & 79.0 & 47 & 80.0 & 37 & 6.0 \\
\hline 2-Year Degree & 8 & 7.0 & 5 & 7.5 & 3 & 17.0 \\
\hline Direct Employment & 13 & 12.0 & 5 & 7.5 & 8 & 0 \\
\hline Undecided & 2 & 2.0 & 2 & 5.0 & 0.0 \\
\hline
\end{tabular}

Table 2 lists the self-reported academic success of student-athletes. The current college grade point average of student-athletes is as follows: 51 athletes (50\%) listed their GPA between 2.1-3.0, 47 athletes (46\%) listed their GPA between 3.1-4.0, and 5 athletes (5\%) listed their GPA between 1.1-2.0.

Table2: Self-Reported Grade Point Average (GPA) of Student-Athletes

\begin{tabular}{|l|l|l|}
\hline Students & \multicolumn{1}{|c|}{ Percent (\%) } & \multicolumn{1}{c|}{ GPA Range } \\
\hline 0 & 0 & $0.1-1.0$ \\
\hline 5 & 5 & $1.1-2.0$ \\
\hline 51 & 50 & $2.1-3.0$ \\
\hline 47 & 45 & $3.1-4.0$ \\
\hline
\end{tabular}

International Journal of Sports and Physical Education (IJSPE) 


\subsection{Factors Influencing College Choice Decisions of Community College Student-Athletes}

As shown in Table 3, the combined male and female student-athletes reported the five most significant factors in college selection were: (a) athletics/sports/extracurricular activities $(M=4.24)$, (b) cost of attendance/tuition fees $(M=3.69)$, (c) head coach and coaching staff $(M=3.59)$, (d) availability of desired major/degree programs $(M=3.32)$, and (e) location of college/commuting distance $(M=3.25)$. Least significant factors athletes cited were: (a) gender of head coach $(M=1.72)$, (b) on-campus dorms $(M=1.88)$, (c) high school teammates attending $(M=1.89)$, (d) athletic scholarships $(M=2.22)$, and (e) campus visit $(M=2.42)$.

Table3: College Choice Factors of Community College Student-Athletes

\begin{tabular}{|l|l|l|l|}
\hline Rank & \multicolumn{1}{|c|}{ College Choice Factor } & Mean & SD \\
\hline 1 & Athletics Program & 4.24 & 0.91 \\
\hline 2 & Tuition/Fees & 3.69 & 1.05 \\
\hline 3 & Head Coach & 3.59 & 1.17 \\
\hline 4 & Desired Major & 3.32 & 1.15 \\
\hline 5 & Location of College & 3.25 & 1.12 \\
\hline 6 & Social Atmosphere & 3.11 & 1.13 \\
\hline 7 & Financial Aid & 3.04 & 1.54 \\
\hline 8 & Sports Traditions & 2.84 & 1.20 \\
\hline 9 & Community & 2.82 & 1.10 \\
\hline 10 & Athletic Facilities & 2.78 & 1.16 \\
\hline 11 & Size of Campus & 2.77 & 1.00 \\
\hline 12 & Family Influence & 2.74 & 1.15 \\
\hline 13 & Record of Team & 2.72 & 1.36 \\
\hline 14 & Academic Support & 2.65 & 1.21 \\
\hline 15 & Chance to Travel & 2.54 & 1.16 \\
\hline 16 & Campus Visit & 2.42 & 1.15 \\
\hline 17 & Athletic Scholarship & 2.22 & 1.54 \\
\hline 18 & HS Teammates & 1.89 & 1.12 \\
\hline 19 & On Campus Dorms & 1.88 & 1.28 \\
\hline 20 & Gender of Coach & 1.72 & 1.20 \\
\hline 3.3. & actor & & \\
\hline
\end{tabular}

\subsection{Factors Influencing College Choice Decisions between Gender}

The reported college choice factors were also sub-grouped by gender and the importance of each choice was computed and shown in Table 4 . The five most significant factors reported by males were: (a) athletics/sports/extracurricular activities $(M=4.21)$, (b) head coach and coaching staff $(M=3.84)$, (c) attendance/tuition fees $(M=3.51)$, (d) availability of desired major/degree programs $(M=3.18)$, and (e) social atmosphere of the team $(M=3.18)$. The five least significant factors reported by men were: (a) high school teammates attending $(M=1.79)$, (b) gender of head coach $(M=1.98)$, (c) oncampus dorms $(M=1.98)$, (d) athletic scholarships $(M=2.24)$, and (e) student populations/size of college $(M=2.51)$.

The five most significant factors reported by females are as follows: (a) athletics/ sports/ extracurricular activities $(M=4.21)$, (b) cost of attendance/tuition fees $(M=3.89)$, (c) location of college/commuting distance $(M=3.66)$, (d) availability of desired major/degree programs $(M=3.47)$, and (e) financial aid $(M=3.21)$. The five least significant factors women stated were: (a) gender of head coach $(M=1.47)$, (b) on campus dorms $(M=1.68)$, (c) high school teammates attending $(M=$ $1.98)$, (d) athletic scholarships $(M=2.17)$, and (e) campus visit(s) $(M=2.28)$.

Table4: College Choice Factors of Community College Student-Athletes by Gender

\begin{tabular}{|l|l|l|l|l|l|l|}
\hline & \multicolumn{2}{|c|}{ Overall } & \multicolumn{2}{c|}{ Female } & \multicolumn{2}{c|}{ Male } \\
\hline College Choice Factor & Mean & SD & Mean & $S D$ & Mean & $S D$ \\
\hline Athletics Program & 4.24 & 0.91 & 4.21 & 0.91 & 4.21 & 0.94 \\
\hline Tuition/Fees & 3.69 & 1.05 & 3.89 & 1.09 & 3.51 & 1.02 \\
\hline Head Coach & 3.59 & 1.17 & 3.17 & 1.40 & 3.84 & 0.81 \\
\hline Desired Major & 3.32 & 1.15 & 3.47 & 1.14 & 3.18 & 1.17 \\
\hline Location of College & 3.25 & 1.12 & 3.66 & 1.07 & 2.93 & 1.05 \\
\hline Social Atmosphere & 3.11 & 1.13 & 2.94 & 1.22 & 3.18 & 1.05 \\
\hline Financial Aid & 3.04 & 1.54 & 3.21 & 1.59 & 2.84 & 1.49 \\
\hline Sports Traditions & 2.84 & 1.20 & 2.58 & 1.16 & 2.95 & 1.16 \\
\hline
\end{tabular}

International Journal of Sports and Physical Education (IJSPE)

Page 4 


\begin{tabular}{|l|l|l|l|l|l|l|}
\hline Community & 2.82 & 1.10 & 2.94 & 1.10 & 2.67 & 1.09 \\
\hline Athletic Facilities & 2.78 & 1.16 & 2.73 & 1.20 & 2.75 & 1.14 \\
\hline Size of Campus & 2.77 & 1.00 & 3.09 & 1.04 & 2.51 & 0.87 \\
\hline Family Influence & 2.74 & 1.15 & 2.91 & 1.20 & 2.60 & 1.07 \\
\hline Record of Team & 2.72 & 1.36 & 2.48 & 1.40 & 2.80 & 1.27 \\
\hline Academic Support & 2.65 & 1.21 & 2.67 & 1.28 & 2.53 & 1.09 \\
\hline Chance to Travel & 2.54 & 1.16 & 2.32 & 1.20 & 2.73 & 1.15 \\
\hline Campus Visit & 2.42 & 1.15 & 2.28 & 1.12 & 2.54 & 1.18 \\
\hline Athletic Scholarship & 2.22 & 1.54 & 2.17 & 1.50 & 2.24 & 1.57 \\
\hline HS Teammates & 1.89 & 1.12 & 1.98 & 1.12 & 1.79 & 1.11 \\
\hline On Campus Dorms & 1.88 & 1.28 & 1.68 & 1.09 & 1.98 & 1.32 \\
\hline Gender of Coach & 1.72 & 1.20 & 1.47 & 1.04 & 1.98 & 1.32 \\
\hline
\end{tabular}

Male and female responses in this study indicated there were significant differences based on size of campus, surrounding community where college is located, head coach and coaching staff, and gender of head coach. As shown in Table 5, male respondents rated the following factors significantly higher than their female counterparts: gender of head coach and head coach and coaching staff. However, females rated the following factors significantly higher than their male counterparts: location of college (commuting distance) and size of college (student population). Males in the study listed three of the top five factors as athletically related rather than academically related. Conversely, only one of the top five factors listed by women was athletically related "the offering of athletics"; however, it was the number one, and most important factor.

Table5: Mean Differences in Gender

\begin{tabular}{|l|l|l|l|l|l|}
\hline \multirow{2}{*}{ Factor } & Mean Scores & $\boldsymbol{T}$ & $\boldsymbol{d} \boldsymbol{p}$ & $\boldsymbol{p}$-value \\
\cline { 2 - 6 } & Male & Female & & & \\
\hline Gender of Head Coach & 1.98 & 1.47 & 2.177 & 102 & .032 \\
\hline Size of Institution & 2.51 & 3.09 & -3.082 & 102 & .003 \\
\hline Location of Institution & 2.93 & 3.66 & -3.499 & 102 & .001 \\
\hline Head Coach and Coaching Staff & 3.84 & 3.17 & 2.986 & 100 & .004 \\
\hline
\end{tabular}

\section{DISCUSSION}

Student-athletes who are not able to be admitted at an NCAA institution can be eligible at an NJCAA institution due to different eligibility standards. Additionally, the opportunity to play as a freshman and sophomore is greater at an NJCAA institution. This would give athletes two additional years to develop, which may open more opportunities for them to compete at a higher level in contrast to their option of joining right out of high school (NJCAA, 2019).Seventy-nine percent of two-year college athletes reported a goal to transfer to four-year colleges at the completion of their participation. One could conclude that the majority of student-athletes at two-year colleges have the goal of competing at NCAA institutions.

NJCAA student-athletes, both male and female, identified athletic programs as the most important college selection criteria. Athletics program was the only choice factor that had a mean score above 4 . Further analysis indicated that men listed the top three college selection factors in the athletic category rather than academic related. They were: (a) athletics program, (b) head coach and coaching staff, and (c) social atmosphere of the team. Females in the study had only one athletically related factor in their top five selection factors; although it was the top factor. Recruiting student-athletes to NJCAA institutions is different than recruiting overall student body. Showcasing how the institution's athletic programs are supported may be crucial in recruiting these student-athletes.

College selection decisions between NCAA and NJCAA student-athletes had some similarities including the importance of a head coach and athletic programs (Pampaloni, 2010; Popp, Pierce, \& Hums, 2011; Huffman \& Cooper, 2012). However, the most important factor influencing a studentathlete's decision to attend an NJCAA institution is the athletics program. It may be important for college coaches, recruiters, administrators, and institutions to inform student-athletes about the athletic opportunities and quality of athletic programs that exist on campuses sanctioning NJCAA athletics. Other influential factors in order of importance from this study were the cost of attendance/tuition fees, head coach and coaching staff, availability of desired major/degree programs, and location of college/commuting distance. These factors would also be important to address in marketing materials and in conversations. 
The student-athlete selection criteria between baccalaureate and non-baccalaureate colleges indicate that NJCAA student-athlete college selection is different from NCAA student-athlete college selection. College selection factors in NCAA baccalaureate institutions are generally based on academic reasons, not athletic reasons. This is true for student-athletes and non-athletes (both male and female). Although factors influencing college selection may be either academic or athletic, the research indicated that academic factors are usually the most influential. For example, academic major, degree programs, excellent teachers, academic reputation, and career opportunities after college were the most significant factors selected by athletes attending four-year universities. However, the higher the NCAA division of athletic competition (DI), the more significant the athletic factors became (Pampaloni, 2010; Popp, et al., 2011; Huffman et al., 2012).

Several studies noted the selection criteria of students in four-year institutions could be classified as academic (Pampaloni, 2010; Popp, et al., 2011; Huffman et al., 2012). This finding is in contrast to NJCAA student-athletes surveyed who reported the number one reason they are attending a particular two-year college is due to the offering of varsity athletics. For example, Fielitz (2001) found the most important factor in attending the United States Military Academy was excellent teachers followed by an opportunity to play at the Division I level, academics/academic reputation of the academy, and the athletic tradition/reputation. Similarly, Gabert et al. (1999) concluded the most significant selection factors for freshmen student-athletes at four-year colleges were academic and degree programs and services, followed by the influence of others, and location of the school. A study by Letawsky et al. (2003) at a large four-year university found the most important factors influencing college selection were degree program options, head coach, academic support services, community where campus is located, and school sports traditions. Goss et al. (2006) found similar results at small four-year colleges and universities, where academic major of choice, playing time, head coach, academic support services, and spiritual guidance were the most significant factors.

Further analysis of data based on the gender of the athletes provides an interesting comparison. After reviewing the top five factors in this study, men selected more "athletically related factors" (i.e., head coach and coaching staff, and social atmosphere of the team) as influential, whereas women selected "non-athletic" criteria such as tuition and fees, location, desired major and financial aid as more influential. However, both females and males stated athletic programs as the number one factor for attending. These findings are very similar to those found in a study of female basketball players participating in the Pennsylvania State Athletic Conference (PSAC). The female student-athletes reported the availability of career choice, the academic program at the university, and distance from home as significant factors (Heilman, 1988). In 1999, Baumgartner studied Division II recruited female intercollegiate soccer players in the Pennsylvania State Athletic Conference (PSAC) and found that academic reputation of the institution and the reputation of their chosen major of study were the most significant factors in university selection. Other less significant factors in the sub-groups were opportunity to play, conference reputation, availability and reputation of the major of interest and overall academic reputation, honesty of the head coach, and academic reputation of the institution. Osborne (2001) found that female student-athletes attending Pennsylvania State Athletic Conference (PSAC) universities, reported academic reputation of the university, athletic scholarships, and coaching staff were the factors most influential in college selection. Similarly, Kankey and Quarterman (2007) studied Division I softball players and determined availability of major or academic program, head coach, career opportunities after graduation, and social atmosphere of the team were the most important factors.

Because recruiting budgets and recruiting opportunities are very limited at NJCAA institutions, it is particularly important for these efforts to be focused, efficient, and effective. Coaches and administrators in athletic departments must prepare a recruiting plan that communicates with students in a way that is effective and speaks to the issues student-athletes identified as important. First, NJCAA institutions should prepare recruiting materials that will make high school students aware of the sports offered at the college. Both men and women listed athletic programs as the number one decision factor in college selection. Additionally, admissions and athletic departments should disseminate information to high school coaches and counselors to assist in informing students of the post-secondary athletic opportunities at NJCAA institutions.

Due to the differences in choice factors between males and females on the top enrollment selection factors athletic departments may want to fine-tune their recruiting efforts. Males rated the head coach 
and coaching staff higher than females, so recruiting efforts by the coaching staffs could be based on more direct personal interaction or information with male student-athletes. Female athletes, however, choose NJCAA institution because of more economical reasons such as campus location, commuting distance, and size of institution. Materials that feature these attributes may be developed and recruiters should include this information when talking with prospective student-athletes.

Finally, both males and females listed the tuition cost as a "top three" enrollment decision factor. For example, the tuition cost to attend a public two-year institution in Minnesota averages $\$ 4,565$ per year. Public four-year colleges in Minnesota average $\$ 6,083$ per year. These figures are based on a college cost comparison of annual tuition and fees (2008-2009 academic year) completed by the Minnesota State Colleges and Universities Office of the Chancellor. Room and board expenses are an additional cost in both cases. Public institutions have a variety of grants, loans, work-study opportunities, and scholarships available to qualified students. Recruiters at two-year colleges should be trained to answer questions about the cost of tuition and financial aid options. Tuition at a private two-year college can be as high as $\$ 16,956$ per year and private four-year college tuition can be as high as \$38,046 (Minnesota State Colleges and Universities, 2008). For prospective students concerned about the high cost of tuition, the comparative financial advantage of attending a public two-year institution should be included in the recruiting materials.

\section{LIMITATIONS AND FUTURE DIRECTIONS}

A limitation of this investigation was that it examined all sports at NJCAA institutions and that all participants were from institutions located in the Midwest. Despite these limitations, this investigation provides some useful findings and recommendations for future investigations.

The first recommendation for future investigations is the analysis of specific sports. This would allow coaches of the individual sports to better cater their recruiting to the sport-specific needs of potential student-athletes. The second recommendation would be to compare NJCAA Divisions, including scholarship and non-scholarship student-athletes to better understand the degree to which nonscholarship NJCAA Division III student-athletes have different rankings in choice factors compared to Division I and II scholarship counterparts.

\section{REFERENCES}

[1] Ashburn, E. (2007, October). To increase enrollment, community colleges add more sports. Education Digest, 73(2), 58-60.

[2] Baumgartner, A. (1999). Factors that influence Division II recruited female intercollegiate soccer studentathletes in selecting their university of choice. Unpublished thesis, Slippery Rock University, Pennsylvania.

[3] Canale, J. R., \& Dunlap, L. (1996). The relative importance of various college characteristics to students in influencing their choice of a college. College Student Journal, 30(2), 214-216.

[4] California Community College Athletic Association (2019). About the CCCAA. Retrieved from https:// www.cccaasports.org/about/about.

[5] Crowley, C. (2004). Factors influencing college choice among track and field student athletes at NCAA D1 conference HBCUs (Doctoral dissertation, 18 Florida State University). Retrieved from http://purl.flvc. org/fsu/fd/FSU_migr_etd-2982

[6] Fielitz, L. R. (2001). Factors influencing the student-athletes' decision to attend the United States Military Academy. Unpublished dissertation. University of New Mexico, Mexico.

[7] Fulks, D.L. (2000). Revenues and expenses of divisions II and III intercollegiate athletics programs: Financial trends and relationships-1999. Indianapolis, IN: National Collegiate Athletic Association

[8] Gabert, T., Hale, J., \& Montalvo, G. (1999). Differences in college choice factors among freshman student-athletes. The Journal of College Admission, 164, $20-29$.

[9] Goss, B. D., Jubenville, C. B., \&Orejan, J. (2006). An examination of influences and factors on the institutional selection processes of freshmen student-athletes at small colleges and universities. Journal of Marketing for Higher Education, 16(2), 105-134.

[10] Hagedorn, L. S., \& Horton, D. J. (2009). Conclusions and parting words from the editors. New Directions For Community Colleges, 147, 85-91.

[11] Heilman, L. L. (1988). Factors influencing college selection by female basketball players participating in the Pennsylvania State Athletic Conference. Unpublished thesis, Slippery Rock University, Pennsylvania.

[12] Huffman L. T. \& Cooper C. G. (2012). I'm taking my talents to....an examination of hometown socioeconomic status on the college-choice factors of football student-athletes at a southeastern university. Journal of Issues in Intercollegiate Athletics. 5, 225-246 
[13] Kankey, K., \& Quarterman, J. (2007). Factors influencing the university choice of NCAA Division I softball players. The Smart Journal, 3(2), 35-49.

[14] Kissinger, D. B., \& Miller, M. T. (2009). The contemporary college student athlete as a subpopulation. In D. B. Kissinger, \& M. T. Miller (Eds.), College student-athletes: Challenges, opportunities, and policy implications (pp. 1-7). Charlotte, SC: Information Age Publishing.

[15] Letawsky, N. R., Palmer, C. J., \& Schneider, R. G. (2005). Factors influencing the college selection process of male and female student-athletes. International Journal of Sport Management, 6(1), 84-97.

[16] Letawsky, N. R., Schneider, R. G., Pedersen, P. M., \& Palmer, C. (2003). Factors influencing the college selection process of student-athletes: Are their factors similar to non-athletes? College Student Journal, 37(4), 604-610.

[17] Lim, J., Paulson, L., Romsa, B. Walker, H., \& Romsa, K. (2017). Analysis of factors influencing the college choice decisions of NCAA Division II elite track and field athletes. International Journal of Sports and Physical Education, 3(2), 22-31.

[18] Minnesota State Colleges and Universities. (2008). Go Places. College Cost Comparison of Annual Tuition and Fees [Brochure].

[19] National Collegiate Athletic Association. (2019). NCAA student-athletes. Retrieved from http://www. ncaa.org/student-athletes.

[20] National Collegiate Athletic Association. (2018). Number of NCAA college athletes reaches all-time high. Retrieved from http://www.ncaa.org/about/resources/media-center/news/number-ncaa-college-athletesreaches-all-time-high

[21] National Junior College Athletic Association. (2019). Information for a Prospective NJCAA StudentAthlete. Retrieved from NJCAA.org.

[22] Nunnally, J. C., \& Bernstein, I. H. (1994) Psychometric theory (3rd ed.). New York, NY: McGraw-Hill, Inc.

[23] Osborne, C. A. (2001). Factors influencing female student-athletes' decisions to attend a Pennsylvania State Athletic Conference University. Unpublished thesis, Slippery Rock University, Pennsylvania.

[24] Pampaloni, A. M. (2010). The influence of organizational image on college selection: what students seek in institutions of higher education. Journal of Marketing for Higher Education, 20(1), 19-48. doi: 10. 1080/08841241003788037

[25] Perna, L. W. (December 2014). Intercollegiate Athletics (What's AHEAD: Key Trends in Higher Education No. 4). Philadelphia, PA: Alliance for Higher Education and Democracy, Graduate School of Education, University of Pennsylvania.

[26] Popp, N., Pierce, D., \& Hums, M. A. (2011). A comparison of the college selection process for International and domestic student-athletes at NCAA Division I universities. Sport Management Review, 14(2), 176-187.

[27] Stinson, J.L. \& Howard, D.R. (2007). Athletic success and private giving to athletic and academic programs at NCAA institutions. Journal of Sport Management, 21(2), 235-264.

[28] Stinson, J.L. \& Howard, D.R. (2004). Scoreboards vs. mortarboards: Major donor behavior and intercollegiate athletics. Sport Marketing Quarterly, 13(2), 129 - 140.

[29] Toma, J. D., \& Cross, M. E. (1998). Intercollegiate athletics and student college choice: Exploring the impact of championship seasons on undergraduate applications. Research in Higher Education, 39(6), 633-661.

[30] Tucker, I. B. (2004). A reexamination of the effect of big-time football and basketball success on graduation rates and alumni giving rates. Economics of Education Review, 23(4), 655- 661.

[31] Upthegrove, T. R., Roscigno, V. J., \& Charles, C. Z. (1999). Big money collegiate sports: Racial concentration, contradictory pressures, and academic performance. Social Science Quarterly, 80(4), 718-737.

Citation: Nicole Meulemans, et.al. "Factors Influencing the College Choice Decisions of Community College Student-Athletes" International Journal of Sports and Physical Education (IJSPE), vol 5, no. 3, 2019, pp. 1-8. doi: http://dx.doi.org/10.20431/2454-6380.0503001.

Copyright: (C) 2019 Authors. This is an open-access article distributed under the terms of the Creative Commons Attribution License, which permits unrestricted use, distribution, and reproduction in any medium, provided the original author and source are credited. 